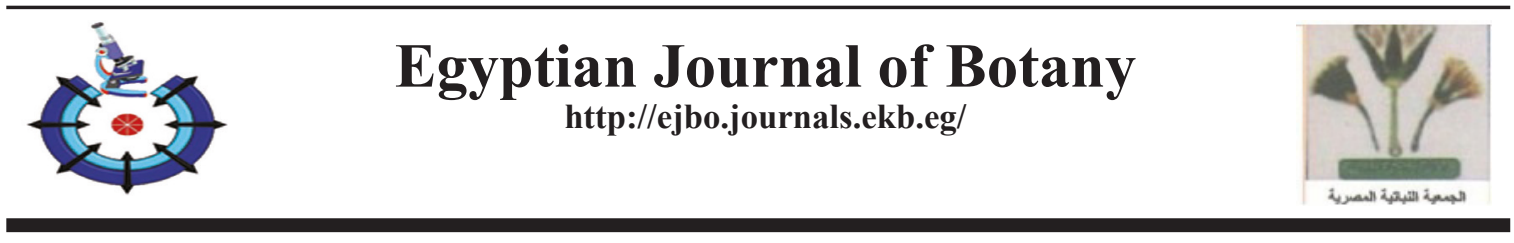

\title{
Bioremediation of Ammonium and Phosphates and their Effect on the Macroalgae Dictyota dichotoma (Hudson) Lamouroux Native to the Red Sea Coast, Egypt
}

\author{
Amany G. Madkour ${ }^{(1)}$ Sarah H. Rashedy ${ }^{(2)}$, Hussein E. Touliabah ${ }^{(3) \#}$ \\ (1) Marine Pollution Láb. Marine Environment Division, National Institute of \\ Oceanography and Fisheries, Hurghada Branch, Red Sea Province, Egypt; \\ ${ }^{(2)}$ Hydrobiology Lab, Marine Environment Division, National Institute of \\ Oceanography and Fisheries, Hurghada Branch, Red Sea Province, Egypt; (3)Botany \\ and Microbiology Department, Faculty of Girls for Science, Education and Arts, Ain \\ Shams University, Cairo, Egypt.
}

\begin{abstract}
N LABORATORY experiments for eleven days, the effect of dissolved ammonium and phosphate on the absorption, growth, and nutritional content of Dictyota dichotoma was examined to determine their potential application as a nutrient biofilter. Five combinations of phosphates and ammonium concentration $(0.8 / 8,2 / 20,4 / 40,6 / 60$, and $8 / 80 \mu \mathrm{mol} / \mathrm{L})$ were added to Sterile seawater. Molar phosphorus/ nitrogen ratio was 1:10. Over a $24 \mathrm{hrs}$ period, $69.2-99.9 \%$ of the available ammonium and $90.7-100 \%$ of the available phosphate were taken up by $D$. dichotoma. The highest specific growth rate was $9.3 \pm 0.2 \%$ day $^{-1}$ at $6 / 60 \mu \mathrm{mol} / \mathrm{L}$ while the lowest was $5.11 \pm 0.3 \%$ day $^{-1}$ at $0 \mu \mathrm{mol} / \mathrm{L}$. On the other hand at $8 / 80 \mu \mathrm{mol} / \mathrm{L}$ the biomass was decreased in the second day of treatment. Total soluble carbohydrate, total soluble protein, and total lipids of the tested $D$. dichotoma were significantly increased with the increase of $\mathrm{PO}_{4}^{-3} /$ $\mathrm{NH}_{4}^{+}$concentration and greater than their respective initial content. The highest averages of total soluble carbohydrate (TSC) $(9.79 \pm 0.45 \%$ dry wt.), total soluble protein (TSP) $(16.3 \pm 0.32 \%$ dry wt.) and total lipid $(8 \pm 0.30 \%$ dry wt.) were observed at the concentration of $6 \mu \mathrm{mol} / \mathrm{L}$ for $\mathrm{PO}_{4}^{-3}$ and $60 \mu \mathrm{mol} / \mathrm{L}$ for $\mathrm{NH}_{4}^{+}$. Based on these results, $D$. dichotoma has a strong absorption capacity for ammonium \& phosphates, and as bioremediator in eutrophic environments can be a promising applicant.
\end{abstract}

Keywords: Ammonium and phosphate nutrients, Biomass, Bioremediator, Dictyota dichotoma, Nutrient uptake, Red Sea, Specific growth rate, Total soluble carbohydrate (TSC), Total soluble protein (TSP).

\section{Introduction}

Assortments of human influences have improved meaningfully in coastal ecosystems all over the world through the past centuries (Murphy et al., 2019). The coastal area gets nutrients from many sources either natural marine or atmospheric sources were reported by Jickells (1998) and Baker (2003). Ben Chekroun et al. (2014) provide an overview of the biomonitoring of organic contaminants used by microalgae in aquatic water bodies and their environmental impact. In addition, nutrients from anthropogenic sources such as finfish farming, aquaculture, and urban use are added to the marine environment.

Marinho et al., (2015) have a hopeful attitude to reduce eutrophic effluents through the cultivation of macroalgae, which lead to eliminating inorganic nutrients through its

"Corresponding author email: touliabah2@hotmail.com

Received 5/1/2020; Accepted 13/5/2020

DOI: $10.21608 /$ ejbo.2020.21997.1430

Edited by: Prof. Dr. Mostafa M. Elsheekh, Faculty of Science, Tanta University, Tanta, Egypt.

(C)2020 National Information and Documentation Center (NIDOC) 
growth. Macroalgae can accumulate nutrients over seawater levels by a factor of up to 105 and maintain specific mechanisms to store enormous quantities of nitrogen and phosphorus in their tissues (Lobban \& Harrison, 1997). Furthermore, by improving internal stores, macroalgae can react to increase nutrient availability (Corey et al., 2013). Dissolved inorganic phosphorus (DIP) and Inorganic Dissolved Nitrogen (IDN) are vital macronutrients to preserve the metabolism and development of marine algae. Nitrogen is considered the major limiting nutrient in marine environments for algal growth. The success of algal farming, therefore, requires knowledge of the algae's nitrogen supplies (Corey et al., 2013). The supreme important sources of nitrogen for macroalgae are ammonium, nitrate, and to some extent, nitrite (Lobban \& Harrison, 1997). Theoretically, ammonium has to be countless because it can be directly assimilated into amino acids, while nitrate must be reduced before amino acid production (Barsanti \& Gualtieri, 2006). The formation of biomolecules, such as phospholipids, proteins, and nuclear acids, is facilitated by phosphorus. Phosphorous plays a significant roles in photosynthesis and respiration because of its conversion to high-energy compounds (Lobban \& Harrison, 1997). The provision of phosphorus can stimulate algal growth and photosynthetic rates (Martins et al., 2011). The survival of Fucus vesiculosus L. could be limited to $50 \%$ by phosphorus (Bergstrom et al., 2003). Macroalgae can be easily harvested, have the efficiency to accumulate nutrients and pollutants. Another advantage is that the biomass of seaweed can be also used to extract bio-based chemicals (Neveux et al., 2015).

De Clerck et al. (2006) claimed that Dictyota Lamouroux is a tropical and subtropical marine species. While, D. dichotoma (Hudson) Lamouroux is one of the most dominant species of the Red Sea coast of Egypt and grows all over the year. The flourishing season of this species was recorded during winter (El-Manawy, 2008; Farghaly \& El-Shoubaky, 2015; Deyab et al., 2017; El-Manawy et al., 2019). Furthermore, Bakar et al. (2019) found that sterol compounds isolated from $D$. dichotoma exhibit antibacterial and antifouling activities, and therefore, it was selected for this study.

This research aimed to assess the capacity of $D$. dichotoma to converts these nutrients into soluble protein, soluble carbohydrates, and lipids under varying concentrations of ammonium and phosphate to absorb and assimilate them, as well as, to maximize their efficacy in their nutrient removal.

\section{Materials and Methods}

\section{Site description}

Location of the selected site situated in a coastal lagoon of the National Institute of Oceanography and Fisheries (NIOF). This located at about $5 \mathrm{~km}$ of NIOF between latitude $27^{\circ} 17^{\backslash} 13^{\prime \prime}$ $\mathrm{N}$ and Longitude $33^{\circ} 46^{\prime} 21^{\prime \prime} \mathrm{E}$ (Fig. 1). This site is characterized by the widely distributed reef flats that extended for about $5 \mathrm{~km}$ seaward with depth variation between $1.5 \mathrm{~m}$ and $6 \mathrm{~m}$. The inshore zone of this site suffers from underground wastewater seepage.

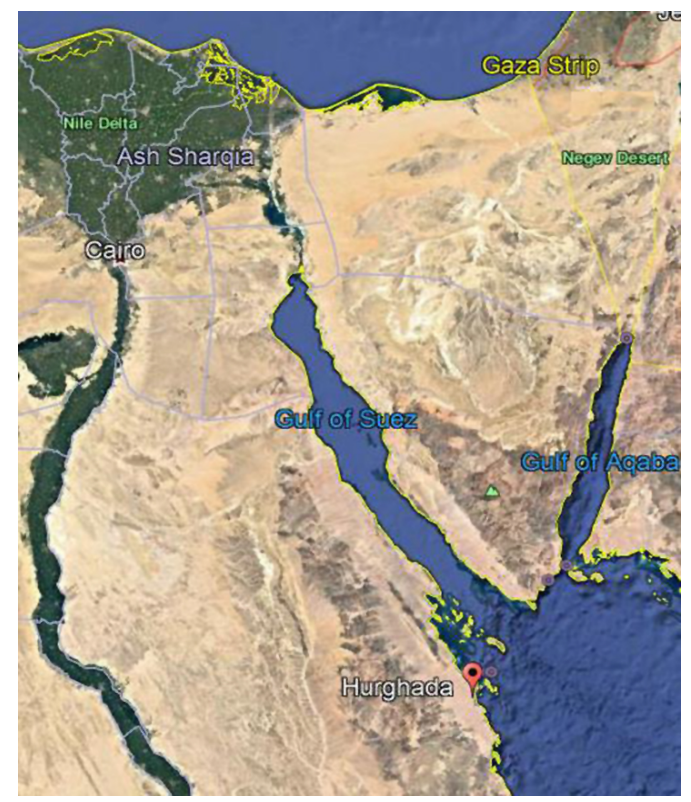

Fig. 1. Site of collection.

\section{Collection and identification of Dictyota dichotoma}

Dictyota dichotoma has been stored in marine bags to prevent evaporation after collected directly and transported to the laboratory inside the icebox (Fig. 2). A portion of this sample was fixed in 4\% formaldehyde, and the other part was distributed for taxonomic identification on herbarium sheets. Alga was identified by morphological characters like the pigment, structure of the vegetative thallus with reproductive organs, and other characters using taxonomic references (Aleem, 1978; Coppejans \& Beeckman, 1990; Sahoo, 
2001). The name of this species was identified according to Guiry \& Guiry (2019).

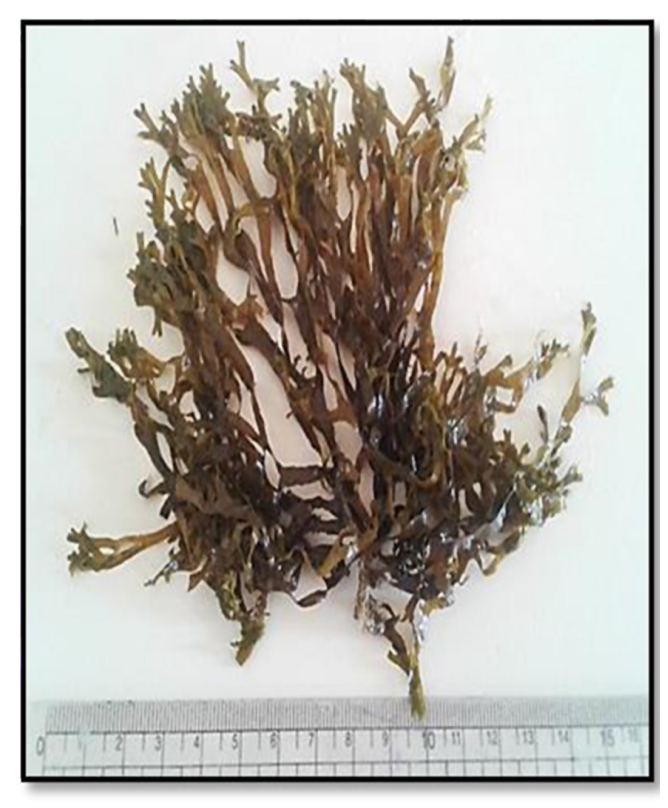

Fig. 2. Dictyota dichotoma.

To remove small epiphytes, sand, surface debris, and invertebrates, healthy fronds of collected fresh seaweeds were washed in seawater. It is necessary to properly clean the plants for consistent results (Buapet et al., 2008). Wet weight of $20 \pm 2 \mathrm{~g} D$. dichotoma fronds were grown in 20L sterile seawater aerated glass jars. The nutrient media levels were $0.4 \mu \mathrm{mol} / \mathrm{L}$ for phosphate, $0.6 \mu \mathrm{mol} / \mathrm{L}$ for ammonia, $0.135 \mu \mathrm{mol} / \mathrm{L}$ for nitrate, and $0.011 \mu \mathrm{mol} / \mathrm{L}$ for nitrite in the incubation water.

\section{Experimental design}

Experiments were performed with a ratio of $2 \mathrm{~g}$ of algal biomass per $1 \mathrm{~L}$ culture medium in Erlenmeyer flasks (1L). Treatments consisted of sterilized seawater supplemented by modified medium (Von Stosch media, this medium with iron salts, Manganese, EDTA, and three vitamins, not including phosphate and nitrate), according to Ribeiro et al. (2017). Ammonium $\left(\mathrm{NH}_{4} \mathrm{Cl}\right)$ and phosphate $\left(\mathrm{Na}_{2} \mathrm{HPO}_{4} \cdot 12 \mathrm{H}_{2} \mathrm{O}\right)$ were added to the Von Stosch modified medium in order to obtain a phosphorous/ nitrogen $(\mathrm{P} / \mathrm{N})$ ratio of $1: 10$. The control of these experiments lacks ammonium or phosphate but contains vitamins and trace elements. Ammonium concentrations in various treatments were $0,8,20,40,60$ and $80 \mu \mathrm{mol} / \mathrm{L}$. On the other hand, the phosphorus concentrations were $0,0.8,2,4,6$, and $8 \mu \mathrm{mol} / \mathrm{L}$. Control and different treatment either by nitrogen or phosphorus, were in three replicates. The light intensity was $20 \mu \mathrm{mol}$ photons $\mathrm{m}^{-2} \mathrm{sec}^{-1}$ with 16 : 8hrs light: dark period for 12 days. The flasks were aerated by air pump. The cultures were refreshed every 4 days. Temperature, $\mathrm{pH}$, Salinity and dissolved oxygen were measured daily by Multi-parameter Instrument (YSI ProODO).

\section{Measurement of nutrient uptake}

The sampling periods from the flasks under experiments were $0,1,4,8$ and $24 \mathrm{hrs}$. Dissolved ammonium $\left(\mathrm{NH}_{4}^{+}\right)$and dissolved inorganic phosphate $\left(\mathrm{PO}_{4}^{3-}\right)$ were determined spectrophotometrically according to the methods described by APHA (2005). For each nutrient, the Nutrient Uptake Efficiency (NUE) was determined using Kang et al. (2011) formula as follows :

$$
\operatorname{NUE}=\left[\left(c_{i}-c_{f}\right) / c_{i}\right] \times 100
$$

where, NUE is Nutrient Uptake Efficiency in percentage. $c_{i}$ and $c_{f}$ are the initial and the final concentrations $(\mu \mathrm{mol} / \mathrm{L})$ of each nutrient.

Macroalgae nutrient uptake was measured on the basis of reduced concentration in the culture medium of a given nutrient (Tremblay-Gratton et al., 2018).

\section{Growth rate of Dictyota dichotoma}

The fresh weight of $D$. dichotomas were determined at the start of the experiment and every 2 days until the end after the drying using tissue paper and the specific growth rate (SGR, \% $\mathrm{d}^{-1}$ ) was calculated as follows:

$$
\mathrm{SGR}=\frac{(\ln W i-\ln W i-1) x 100}{t}
$$

where: Wi represents the fresh weight collected at time $\mathrm{i}, \mathrm{Wi}-1$ represents the fresh weight collected at time $i-1, t$ represents days (d) between $i$ and i-1.

Determination of nutritional composition of Dictyota dichotoma

The total soluble carbohydrates (TSC) were estimated according to Hedge \& Hofreiter (1962). On the other hand, the total soluble proteins (TSP) were measured according to AOAC (2000). 
Statistical analysis

One-way ANOVA and Fisher's 95\% significance level grouping test were used to check the influence of enrichment of different nutrient concentrations on the growth rate, the absorption of nutrients, and the nutritional content of D. dichotoma (Cambell, 1989). All statistical analyses were carried out using Minitab ® software (Version 16).

\section{$\underline{\text { Results }}$}

Taxonomic description of Dictyota dichotoma

Algal sample was morphologically identified as presented in the literature. The latest accepted name was $D$. dichotoma (Hudson) J.V. Lamouroux.

Physical and chemical conditions of the culture

Culture temperature, $\mathrm{pH}$, salinity, and dissolved oxygen were measured during the 11 days of experiment and the results were illustrated in Table 1.

TABLE 1. Physical and chemical conditions of the culture during the experiment.

\begin{tabular}{lc}
\hline Parameters & Measurements \\
\hline Temperature $(\mathrm{C})$ & $25.6 \pm 0.6$ \\
$\mathrm{pH}$ & $8.4 \pm 0.5$ \\
Salinity (ppt) & $41.2 \pm 0.7$ \\
DO $(\mathrm{mg} / \mathrm{L})$ & $4.4 \pm 0.6$ \\
\hline
\end{tabular}

Each value represents the average \pm SD

Bioremediation of ammonium and phosphate by Dictyota dichotoma

The different concentrations of ammonium $(8,20,40$, and $60 \mu \mathrm{mol} / \mathrm{L})$ and phosphate $(0.8,2$, 4 and $6 \mu \mathrm{mol} / \mathrm{L})$ were decreased with time until reaching their minimum values of $0.001 \mu \mathrm{mol} / \mathrm{L}$ at $24 \mathrm{hrs}$. The highest concentration of $\mathrm{NH}_{4}^{+}$ $(80 \mu \mathrm{mol} / \mathrm{L})$ and $\mathrm{PO}_{4}^{3-}(8 \mu \mathrm{mol} / \mathrm{L})$ was reached at $24 \mathrm{hrs}$ to $21.23 \pm 0.32$ and $0.75 \pm 0.07$, respectively (Fig. 3). The uptake of different concentrations of $\mathrm{NH} 4+$ and $\mathrm{PO}_{4}^{3-}$ were significantly different at $\mathrm{P}<0.05$. The highest uptake efficiency of $\mathrm{NH}_{4}^{+}$at $24 \mathrm{hrs}$ was $99.98 \pm 0.01 \%$ occurred for the conc. of $8 \mu \mathrm{mol} / \mathrm{L}$, while the lowest uptake efficiency of $\mathrm{NH}_{4}^{+}$was $69.18 \pm 3.2 \%$ occurred for the conc. of $80 \mu \mathrm{mol} / \mathrm{L}$ (Fig. 4).

Phosphate concentration levels were close to fluctuations in concentrations of ammonium. The highest uptake efficiency of $\mathrm{PO}_{4}^{3-}$ at $24 \mathrm{hrs}$ was
$100 \pm 0.01 \%$ occurred for the conc. of $0.8 \mu \mathrm{mol} / \mathrm{L}$, while the lowest uptake efficiency of $\mathrm{PO}_{4}{ }^{3-}$ was $90.7 \pm 3.2 \%$ occurred for the conc. of $8 \mu \mathrm{mol} / \mathrm{L}$ (Fig. 4).

Effect of phosphate and ammonium (P/N) concentrations on the growth of Dictyota dichotoma

The obtained results displayed that dissimilarities in ammonium and phosphate concentrations have an effect on the growth of $D$. dichotoma. The biomass of $D$. dichotoma increased as $\mathrm{PO}_{4}^{3-} / \mathrm{NH}_{4}{ }^{+}$concentration increased from $0 \mu \mathrm{mol} / \mathrm{L}$ to $6 / 60 \mu \mathrm{mol} / \mathrm{L}$ until the end of the experiment (12 days of incubation), while at $8 / 80 \mu \mathrm{mol} / \mathrm{L}$ the biomass was decreased since the second day of treatment. The highest SGR was $9.3 \pm 0.2 \%$ day $^{-1}$ at $6 / 60 \mu \mathrm{mol} / \mathrm{L}$ while the lowest was $5.11 \pm 0.3 \%$ day $^{-1}$ at $0 \mu \mathrm{mol} / \mathrm{L}$ (Fig. 5). Furthermore, the results indicated that significant differences $(\mathrm{P}<0.001, \mathrm{~F}=11.3)$ were observed in SGR values of untreated $D$. dichotoma (without nutrient addition) and different concentrations of nutrients.

Effect of Phosphate and Ammonium (P/N) Concentrations on the nutritional content of Dictyota dichotoma

TSC of the D. dichotoma was increased with the addition of ammonium plus phosphate after ten days of the experiment compared with its initial content. The highest average of TSC $(9.79 \pm 0.45 \%$ dry wt.) was observed at the concentration of $6 / 60 \mu \mathrm{mol} / \mathrm{L}$, while the lowest average $(5.65 \pm 0.42 \%$ dry wt.) was observed at $0 / 0 \mu \mathrm{mol} / \mathrm{L}$ (Fig. 6).

The findings of the ANOVA showed a significant difference $(\mathrm{P}<0.05)$ between the different concentrations and the initial content.

The tendency TSP of the $D$. dichotoma in this study showed an increase in culture media up to $6 / 60 \mu \mathrm{mol} / \mathrm{L}$ with increases in phosphate and ammonium. The highest average of TSP (16.3 \pm $0.32 \%$ dry wt.) was observed at the concentration of $6 / 60 \mu \mathrm{mol} / \mathrm{L}$, while the lowest average $(8.5 \pm$ $0.52 \%$ dry wt.) was observed at $0 / 0 \mu \mathrm{mol} / \mathrm{L}$ (Fig. 6). The differences between TSP content in different concentrations of $\mathrm{PO}_{4}^{3-} / \mathrm{NH}_{4}{ }^{+}$were statistically significant $(\mathrm{P}<0.05)$. Concerning D. dichotoma lipid content, similar $\mathrm{PO}_{4}^{3-} / \mathrm{NH}_{4}^{+}$ implementation increased its total lipid compared to control group. 

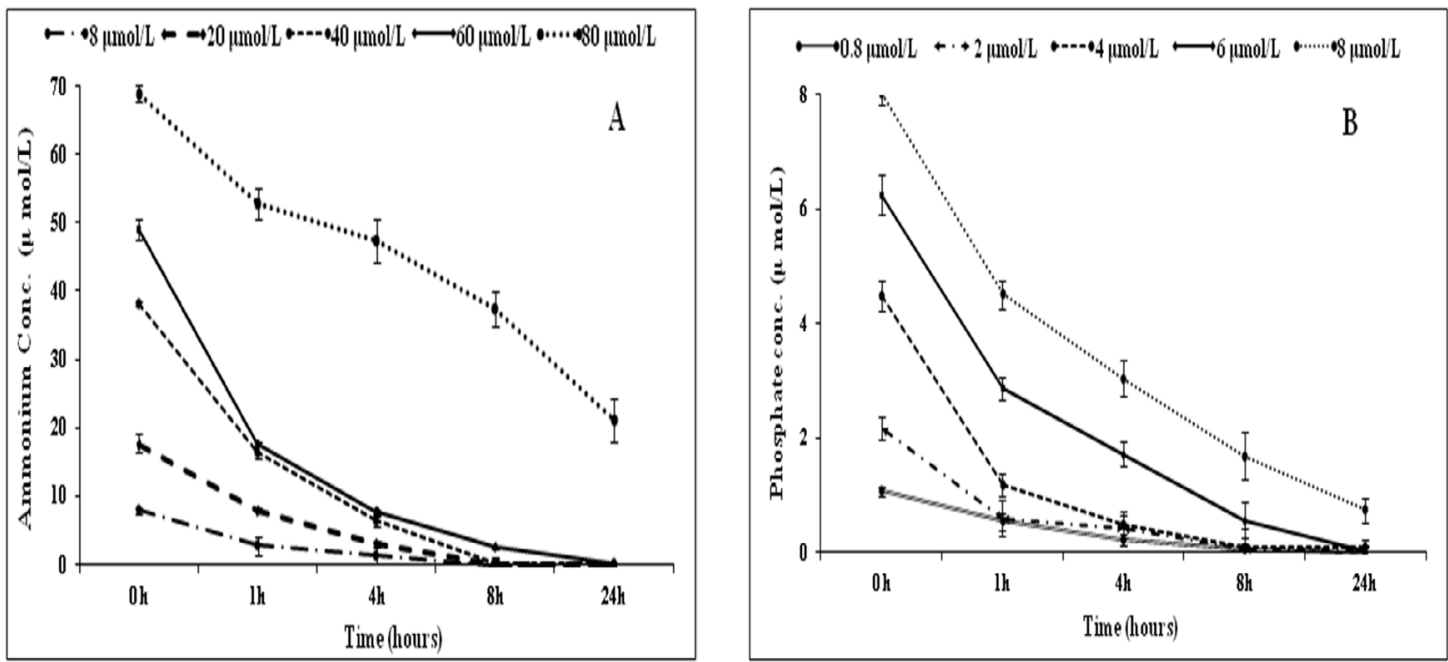

Fig. 3. Nutrients concentration $(\mu \mathrm{mol} / \mathrm{L})$ during 24hrs of treatment; (A) Ammonium and (B) phosphate.
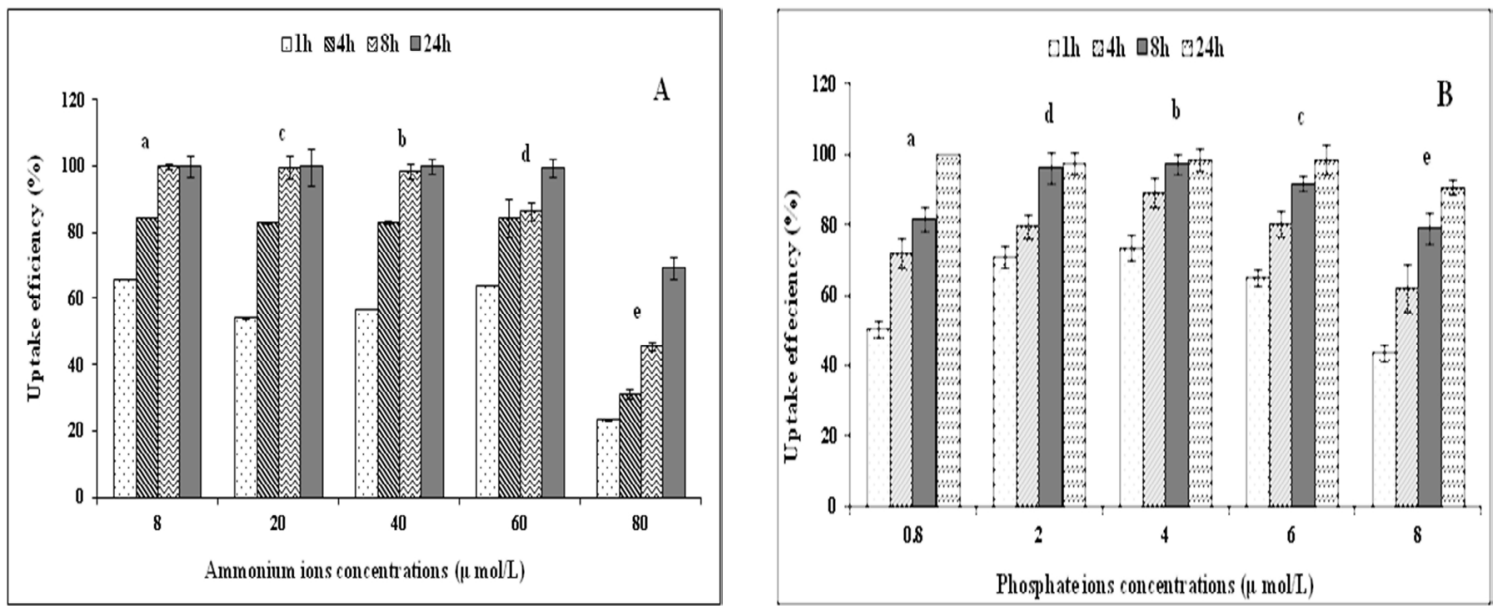

Fig. 4. uptake efficiency (\%) for nutrient; (A) Ammonium and (B) phosphate [The letters indicate significant differences $(\mathbf{P}<0.05)$ among different experimental treatments].

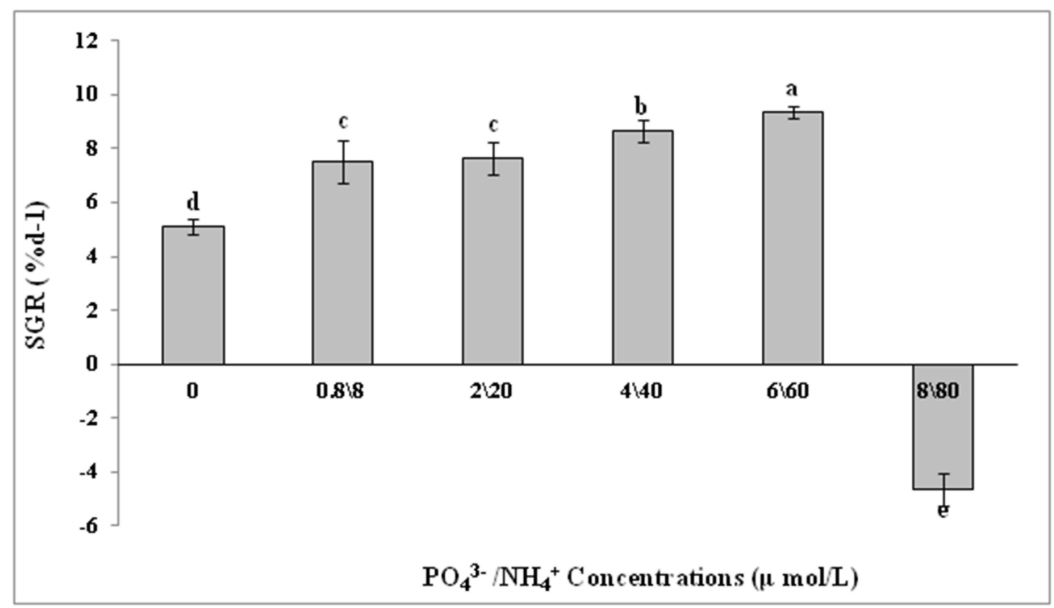

Fig. 5. Specific growth rate (SGR) of $\boldsymbol{D}$. dichotoma cultured for 10 days under supply of different $\mathbf{P O}_{4}^{3-} / \mathrm{NH}_{4}^{+}$ concentrations $(\mu \mathrm{mol} / \mathrm{L})$ [Different letters indicate significant differences $(\mathrm{P}<0.05)$ among different experimental treatments]. 


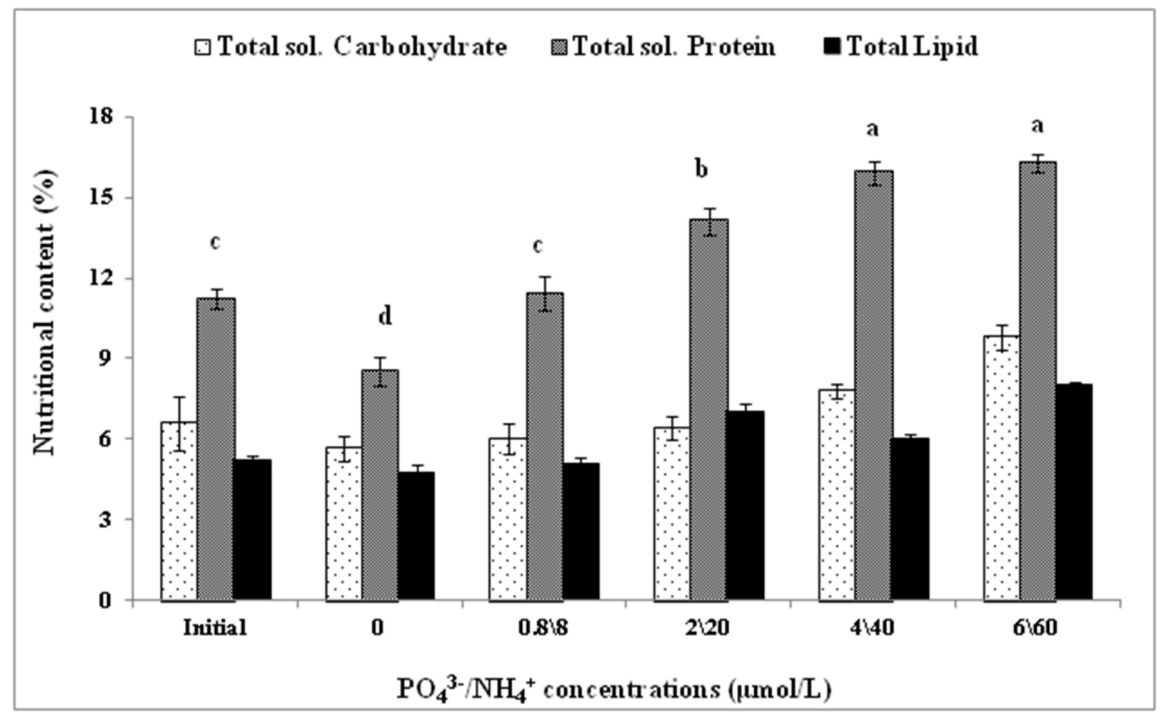

Fig. 6. Nutritional content $(\%)$ of $D$. dichotoma cultured for 10 days under supply of different $\mathbf{P O}_{4}{ }^{3-} / \mathrm{NH}_{4}^{+}$ concentrations $(\mu \mathrm{mol} / \mathrm{L})$ [Different letters indicate significant differences $(\mathrm{P}<0.05)$ among different experimental treatments].

The total lipid content of $D$. dichotoma

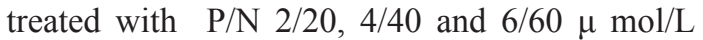
concentrations were $7 \pm 0.24,6 \pm 0.16$, and $8 \pm$ $0.30 \%$ dry wt., which are $34.6 \%, 15.38 \%$, and $53.9 \%$ higher than their relevant initial lipid content.

In addition, the results indicated that a significant difference in the total lipid content of untreated $D$. dichotoma was observed $(\mathrm{P}<0.05)$ if compared to all phosphate and ammonium concentrations (Fig. 6).

\section{Discussion}

Bioremediation of ammonium and phosphate by Dictyota dichotoma

It is well established that, seaweeds have significant attention for their high bioremediation capabilities (Ben Chekroun et al., 2014). This study revealed that two nutrients, $\left(\mathrm{NH}_{4}{ }^{+}\right.$and $\mathrm{PO}_{4}{ }^{3-}$ ), have been significantly removed at different levels by seaweed D. Dichotoma with increased efficiency in biofiltration. Over a $24 \mathrm{hrs}$ period, $69.2-99.9 \%$ of the available ammonium and $90.7-100 \%$ of the available phosphate were taken up by Dictyota dichotoma. It means that this species has the highest capacity to accumulate ammonium and phosphate in its vacuoles. Previous studies using other macroalgae such as Ulva lactuca, it showed ammonia-N and phosphate removal rate of $84.74 \%$ and $41.1 \%$, respectively (Al-Hafedh et al., 2012).

Carneiro et al. (2011) found that Gracilaria cervicornis was able to reduce $\mathrm{NH}_{4}^{+}$ concentrations by $74 \%(2 \mathrm{hrs})$ and $\mathrm{PO}_{4}{ }^{3-}$ by $95.1 \%$ (10hrs) in wastewater treatment using seaweed. Hernández et al. (2006) reported mean filtration efficiencies of $93.2 \%$ for $\mathrm{NH}_{4}^{+}$and $62.2 \%$ for $\mathrm{PO}_{4}^{3-}$ after $7 \mathrm{hrs}$ of incubation in an experiment using Gracilariopsis longissima. On the other hand, the lowest uptake efficiency was obtained at high concentration of ammonium and phosphate of 80 and $8 \mu \mathrm{mol} / \mathrm{L}$, respectively after $24 \mathrm{~h}$ of incubation $\left(69.18 \pm 3.2 \%\right.$ for $\mathrm{NH}_{4}^{+}$and $90.7 \pm 3.2 \%$ for $\mathrm{PO}_{4}^{3-}$ ) and this may be related to nutrient storage in the algal tissues as reported by Yang et al. (2006).

\section{Biomass and growth of Dictyota dichotoma}

Dissolved Inorganic Phosphorus (DIP) and Dissolved Inorganic Nitrogen (DIN) were the essential macronutrients for maintaining macroalgae metabolism and development. The main constituents of phospholipids, nucleic acids, adenosine triphosphate (ATP) are phosphorus $(\mathrm{P})$, and nitronine $(\mathrm{N})$ and they also participate in enzyme reaction adaptation and metabolic pathway regulation (Lubsch \& Timmermans, 2019). In this research, growth rate analysis found a significant effect on a specific growth rate (SGR) of $D$. dichotoma on the treatment of $\mathrm{PO}_{4}^{-3} / \mathrm{NH}_{4}^{+}$at different concentrations. The results 
of this study showed that $D$. dichotoma biomass increased from $0 \mu \mathrm{mol} / \mathrm{L}$ to $6 / 60 \mu \mathrm{mol} / \mathrm{L}$ until the end of the experiment ( 10 days of the incubation), as $\mathrm{PO}_{4}^{-3} / \mathrm{NH}_{4}^{+}$concentration rose. The maximum SGR at $6 / 60 \mu \mathrm{mol} / \mathrm{L}$ was $9.3 \pm 0.2 \%$ day $^{-1}$ while the lowest at $0 \mu \mathrm{mol} / \mathrm{L}$ was $5.11 \pm 0.3 \%$ day $^{-1}$. The results reported were consistent with Joniyas et al. (2016) findings.

In the same context, the SGR of Hypnea cervicornis J. Agardh increased linearly with the addition of ammonium (Ribeiro et al., 2013). Sometimes, some reports related to nutrients and growth of macroalgae claimed that the requirement of nutrients depends on the algal species and its physiology. The biomass was decreased on the second day of treatment at $8 / 80 \mu \mathrm{mol} / \mathrm{L}$, which maybe because of the high concentrations of ammonium. Ribeiro et al. (2017) stated that high concentrations of ammonium $(50-80 \mu \mathrm{mol} / \mathrm{L})$ could be toxic for some seaweed.

Effect of phosphate and ammonium $(P / N)$ concentrations on the nutritional content of Dictyota dichotoma

Seaweed has a physiological mechanism to obtain, utilize, and accumulate various forms of nitrogen from the media. This study revealed that TSC, TSP, and total lipids of the tested $D$. dichotoma were significantly increased with the increase of $\mathrm{PO}_{4}^{-3} / \mathrm{NH}_{4}^{+}$concentration. The highest averages of TSC $(9.79 \pm 0.45 \%$ dry wt.), TSP $(16.3 \pm$ $0.32 \%$ dry wt.) and total lipid ( $8 \pm 0.30 \%$ dry wt.) were observed at the concentration of $6 \mu \mathrm{mol} / \mathrm{L}$ for $\mathrm{PO}_{4}^{-3}$ and $60 \mu \mathrm{mol} / \mathrm{L}$ for $\mathrm{NH}_{4}^{+}$after 12 days of incubation and greater than their respective initial content. Zhang et al. (2010) found that soluble protein content of Potamogeton crispus increases when it is fertilized with $\mathrm{NH}_{4}{ }^{+} \mathrm{N}$ compared with untreated seaweeds. Ismail \& El-Sheek (2017) discussed the nitrogen content in culture media stimulate the biosynthesis of carbohydrates, protein and pigment of the seaweed. Furthermore, the increased $\mathrm{PO}_{4}^{-3} / \mathrm{NH}_{4}{ }^{+}$concentration will led to an increase in total soluble proteins (Joniyas et al., 2016). On the other hand, the data obtained by Suthar et al. (2019) contradict our results. They found that, addition of different concentrations of $\mathrm{P} / \mathrm{N}$ didn't significantly affect lipid synthesis in Ulva fasciata. Their results about biochemical analysis of biomass were $9.30 \pm 0.32 \%$ for proteins, $20.2 \pm 2.51 \%$ for carbohydrates and $6.28 \pm 0.84 \%$ for dry weight.

\section{Conclusion}

The macro-algae are of considerable nutrition value and play an important role in the marine food chain for marine organisms. D. Dichotoma considered being a good candidate for bioremediation of contaminated sites and biofiltration of aquaculture effluent, canning effectively, and efficiently depleting ammonium and phosphate in the aquatic environment. Our consequences demonstrated that D. dichotoma was largely assimilated ammonium and phosphorus with a percentage of $69.2-99.9 \%$ of the available ammonium and $90.7-100 \%$ of the available phosphate. Nutrient concentration in the growth media of $D$. dichotoma affects on the growth rate, where nutritional composition (lipidscarbohydrate and protein) increases with the increase of ammonium and phosphates.on the other hand, at $8 / 80 \mu \mathrm{mol} / \mathrm{L} \mathrm{PO}_{4}{ }^{3-}-\mathrm{NH}_{4}{ }^{+}$concentration, the biomass was decreased. High concentrations of the nutrient are toxic and slow down the growth and may lead to macroalgae death.

Conflict of interests: The authors declare no conflict of interest.

Authors contribution: All are equally.

Ethical approval: Not applicable.

\section{References}

Aleem, A.A. (1978) A preliminary list of algae from Sierra Leone. Botanica Marina, 21, 397-399.

Al-Hafedh, Y.S., Alam, A., Buschmann, A.H., Fitzsimmons, K.M. (2012) Experiments on an integrated aquaculture system (seaweeds and marine fish) on the Red Sea coast of Saudi Arabia: Efficiency comparison of two local seaweed species for nutrient biofiltration and production. Reviews in Aquaculture, 4, 21-31.

AOAC (2000) "Official Methods of Analysis". 17"hed. Association of Analytical Chemists. Washington DC, USA.

APHA (2005) "Standard Methods for the Examination of Water and Wastewater". $21^{\text {st }}$ ed. Washington D.C.

Bakar, K., Mohamad, H., Tan, H.S., Latip, J. (2019) Sterols compositions, antibacterial, and antifouling properties from two Malaysian seaweeds: Dictyota dichotoma and Sargassum granuliferum. Journal

Egypt. J. Bot. 60, No.3 (2020) 
of Applied Pharmaceutical Science, 9(10),047-053.

Baker, A.R. (2003) Atmospheric deposition of nutrients to the Atlantic Ocean. Geophysical Research Letters, 30, 2296.

Barsanti L, Gualtieri P (2006) "Algae: Anatomy, Biochemistry, and Biotechnology". CRC, Boca Raton

Ben Chekroun, K., Sánchez, E., Baghour, M. (2014) The role of algae in bioremediation of organic pollutants. International Research Journal of Public and Environmental Health, 1, 19-32.

Bergstrom, L., Berger, R., Kautsky, L. (2003) Negative direct effects of nutrient enrichment on the establishment of Fucus vesiculosus in the Baltic Sea. European Journal of Phycology, 38, 41-46.

Buapeta, P., Hiranpanb, R., Ritchiec, R.J., Prathepa, A. (2008) Effect of nutrient inputs on growth, chlorophyll, and tissue nutrient concentration of Ulva reticulata from a tropical habitat. Journal of ScienceAsia, 34, 245-252.

Cambell, R.C. (1989) The normal variable in experiments and surveys. In: "Statistics for Biologist", $3^{\text {rd }}$ ed., pp 199-315, Cambridge Univ. Press, Cambridge.

Carneiro, M.A.A., Freire, F.A.M.;, Marinho-Soriano. E. (2011) Study on biofiltration capacity and kinetics of nutrient uptake by Gracilaria cervicornis (Turner) J. Agardh (Rhodophyta, Gracilariaceae). Revista Brasileira de Farmacognosia Brazilian Journal of Pharmacognosy, 21(2), 329-333.

Coppejans, E., Beeckman, T. (1990) Caulerpa (Chlorophyta, Caulerpales) from the Kenyan coast. Nova Hed, 50, 111-125.

Corey, P., Kim, J.K., Duston, K., Garbary, D.J., Prithiviraj, B. (2013) Bioremediation potential of Palmaria palmata and Chondrus crispus (Basin Head): effect of nitrate and ammonium ratio as nitrogen source on nutrient removal. Journal of Applied Phycology, 25, 1349-1358.

De Clerck, O., Leliaert, F., Verbruggen, H., Lane, C., Campos de Paula, J., Payo, D.A., Coppejans, E. (2006) A revised classification of the Dictyoteae (Dictyotales, Phaeophyceae) based on rbcL and 26S ribosomal DNA sequence analyses. Journal of
Phycology, 42, 1271-1288.

Deyab, M.A., El-Katony, T.M., El-Adl, M.F., Ward, F.M (2017) Temporal variation in chemical composition of Dictyota dichotoma (Hudson) J.V. Lamouroux (Dictyotales, Phaeophyceae) from Red Sea Coast, Egypt. Journal of Coastal Life Medicine, 5(4), 1-7.

Duana, Y., Yanga, N., Hua, M., Weib, Z., Bic, H., Huoa,Y., Hea, P. (2019) Growth and nutrient uptake of Gracilaria lemaneiformis under different nutrient conditions with implications for ecosystem services: A case study in the laboratory and in an enclosed mariculture area in the East China Sea. Aquatic Botany, 153, 73-80.

El-Manawy, I.M. (2008) The spatial variability of macroalgal communities and their functional groupings on the fringing reefs of Ghardaqah, Egypt. Egyptian Journal of Phycology, 9, 55-69.

El-Manawy, I.M., Nassar, M.Z., Rashedy, S.H. (2019) Spatial and temporal variations in the nutritional composition of some seaweeds from the Red Sea, Egypt. Egyptian Journal of Phycology, 20, 20-50.

El-Shenody, R.A., Ashour, M., Ghobara, M.M.E. (2019) Evaluating the chemical composition and antioxidant activity of three Egyptian seaweeds: Dictyota dichotoma, Turbinaria decurrens, and Laurencia obtusa. Brazilian Journal of Food Technology, 22, e2018203.

Farghaly, M.S., El-Shoubaky, G.A. (2015) Synopsis of biodiversity and distrebution of macrophytes along the Suez Canal in time and. International Conference on Plant, Marine and Environmental Sciences (PMES-2015) Jan. 1-2, 2015 Kuala Lumpur (Malaysia).

Guiry, M.D., Guiry, G.M. (2019) "Algae Base". Worldwide Electronic Publication, National University of Ireland, Galway; http://www.algaebase.org.

Hedge, J.E., Hofreiter, B.T. (1962) "Carbohydrate Chemistry", Whistler, R.L., Be Miller, J.N. (Eds.), Academic Press, New York.

Hernández, I., Pérez-Pastor, A., Vergara, J.V., MartinezAragón, J.F., Fernández-Engo, A., Pérez-Lloréns, J.L. (2006) Studies on the biofiltration capacity of Gracilariopsis longissima: From microscale to macroscale. Aquaculture, 252, 43-53. 
Ismail, M.M., El-Sheekh, M. (2017) Enhancement of biochemical and nutritional contents of some cultivated seaweeds under laboratory conditions. Journal of dietary supplements, 3(15), 318-329.

Jickells, T.D. (1998) Nutrient biogeochemistry of the coastal zone. Science, 281, 217-223.

Joniyas, A., Surif, M., Abdul Hamid, M., Dehgahi, R. (2016) Effects of ammonium and phosphate concentration on growth, pigment and soluble protein concentration in Gracilaria manilaensis. International Journal of Biosciences, 3, 65-74.

Kang, Y.H., Park, S.R., Chung, I.K. (2011) Biofiltration efficiency and biochemical composition of three seaweed species cultivated in a fish-seaweed integrated culture. Algae, 26, 97-108.

Lobban, C.S., Harrison, P.J. (1997) "Seaweed Ecology and Physiology". Cambridge University Press, New York.

Lubsch, A., Timmermans, K.R. (2019) Uptake kinetics and storage capacity of dissolved inorganic phosphorus and corresponding dissolved inorganic nitrate uptake in Saccharina latissima and Laminaria digitata (Phaeophyceae). Journal of Phycology, 55(3), 637-650.

Marinho, G.S., Holdt, S.L., Birkeland, M.J., Angelidaki, I. (2015) Commercial cultivation and bioremediation potential of sugar kelp, Saccharina latissima, in Danish waters. Journal of Applied Phycology, 27, 1963-1973.

Martins, A.P., Junior,O.N., Colepicolo, P., Yokoya, N.S. (2011) Effects of nitrate and phosphate availabilities on growth, photosynthesis and pigment and protein contents in colour strains of Hypnea musciformis (Wulfen in Jacqu.) J.V. Lamour. (Gigartinales, Rhodophyta). Brazilian Journal of Pharmacognosy, 21(2), 340-348.

Murphy, G.E.P., Wong, M.C., Lotze, H.K. (2019) A human impact metric for coastal ecosystems with application to seagrass beds in Atlantic Canada. FACETS, 4, 210-237.
Neveux, N., Magnusson, M., Maschmeyer, T., et al. (2015) Comparing the potential production and value of high-energy liquid fuels and protein from marine and freshwater macroalgae. Global Change Biology Bioenergy, 7, 673-689.

Ribeiro, A.L.N., Tesima, K.E., Souza, J.M., Yokoya, N.S. (2013) Effects of nitrogen and phosphorus availabilities on growth, pigment, and protein contents in Hypnea cervicornis J. Agardh (Gigartinales, Rhodophyta). Journal of Applied Phycology, 25, 1151-1157.

Ribeiro, A.L.N., Chiozzini, V.G., Braga, E.S., Yokoya, N.S. (2017) Physiological responses and biofilter potential of Hypnea aspera (Rhodophyta, Gigartinales) cultivated in different availabilities of nitrate, ammonium, and phosphate. Journal of Applied Phycology, 29, 683-694.

Sahoo, D. (2001) "Seaweeds of Indian Coast". A.P.H. Publishing Corporation, New Delhi. 283p.

Suthar, P., Gajariaa, T.K., Reddy, C.R.K. (2019) Production of quality seaweed biomass through nutrient optimization for the sustainable land-based cultivation. Journal of Algal Research, 42, 1-8.

Tremblay-Gratton, A., Boussin, J.C., Tamigneaux, É., Vandenberg, G.W., Le François, N.R. (2018) Bioremediation efficiency of Palmaria palmata and Ulva lactuca for use in a fully recirculate coldseawater naturalistic exhibit: Effect of high $\mathrm{NO}_{3}$ and $\mathrm{PO}_{4}$ concentrations and temperature on growth and nutrient uptake. Journal of Applied Phycology, 30, 1295-1304.

Yang, Y.F., Fei, X.G., Song, J.M., Hu, H.Y., Wang, G.C., Chung, I.K. (2006) Growth of Gracilaria lemaneiformis under different cultivation conditions and its effects on nutrient removal in Chinese coastal waters. Aquaculture, 254, 248-55.

Zhang, M., Cao, T., Ni, L., Xie, P., Li, Z. (2010) Carbon, nitrogen and antioxidant enzyme responses of Potamogeton crispus to both low light and high nutrient stresses. Environmental and Experimental Botany, 68, 44-50. 
المعالجة الحيوية للأمونيوم والفوسفات وتأثير ها على الطحالب الكبيرة من نوع الدكتيوتا دايكوتومس (Dictyota dichotoma (Hudson) Lamouroux)، المتوطن في ساحل

البحر الأحمر - مصر (ل البكر

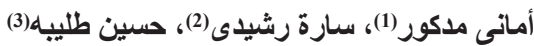

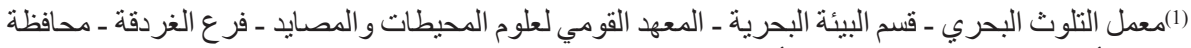

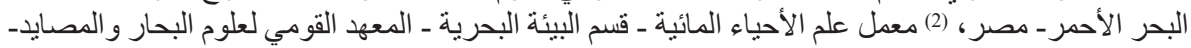

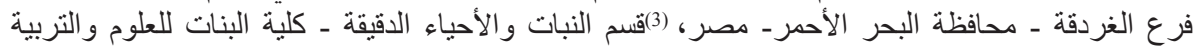

و الآداب- جامعة عين شمس - القاهرة - مصر.

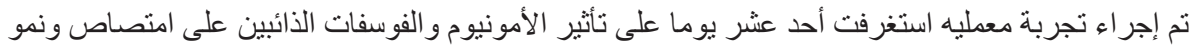

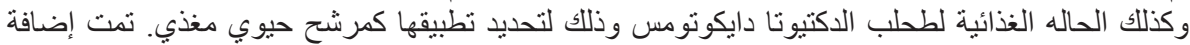

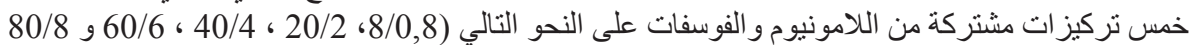

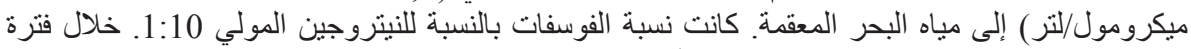

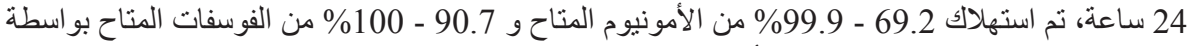
طحلب الدكتيوتا دايكوتومس. تم تسجيل أعلى معدل لنمو الطحلب هو هو

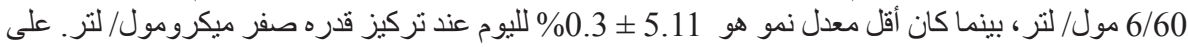

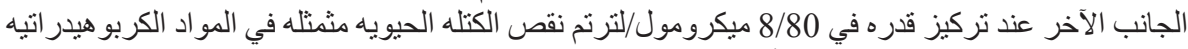

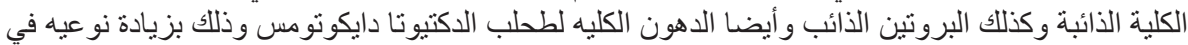

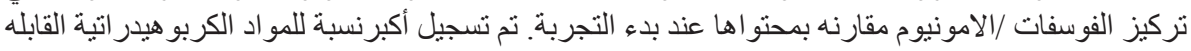

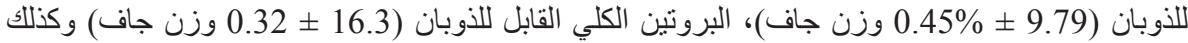

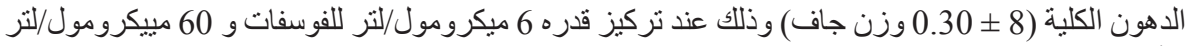

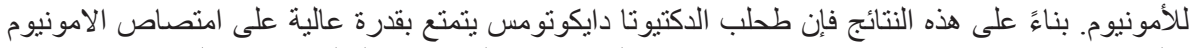
و الفوسفات ويتم استخدامه كمعاج حيوي خاصه في البيئات ذات التركيز ات الت العالية من هذه العناصر. 